Praxis : Jurnal Sains, Teknologi, Masyarakat dan Jejaring | Vol. 4 | No. 1 | September 2021

\title{
Perumusan Strategi Bersaing Pada Laboratorium Klinik Meditest Semarang
}

\author{
Renaldy Prasadana Erickson \\ Program Magister Manajemen, Universitas Katolik Soegijapranata, Semarang \\ email: renaldy.p.e@gmail.com
}

\begin{abstract}
Abstrak
Seiring dengan tren gaya hidup sehat di mana banyak orang-orang menjadi semakin memperhatikan kesehatan diri sendiri, masyarakat semakin aktif untuk memeriksakan kesehatan diri. Terlebih saat ini sedang masa pandemi Covid-19. Pemeriksaan kesehatan bisa dilayani oleh laboratorium klinik. Penelitian ini dilakukan pada laboratorium klinik Meditest yang berlokasi di kota Semarang. Tujuan penelitian ini adalah untuk menghasilkan strategi bersaing bagi Meditest dengan berdasarkan paparan dari Fred R. David. Data untuk penelitian ini berjenis primer yang dikumpulkan dengan wawancara kepada pihak-pihak yang bertanggung jawab atas berjalannya Meditest, yaitu pemilik Meditest, manajer, bagian pengadaan, bagian pemasaran, dan analis lab. Kemudian, data diolah dimulai dengan tahap pertama menggunakan analisis faktor eksternal dan faktor internal, tahap selanjutnya matriks IE dan matriks SWOT, hingga tahap terakhir menggunakan QSPM. Hasil penelitian menunjukkan bahwa strategi bersaing yang tepat digunakan oleh Meditest adalah strategi penetrasi pasar. Kegiatan pemasaran dan promosi perlu lebih digencarkan oleh Meditest, terutama menggunakan media sosial populer sehingga Meditest lebih banyak dikenal orang banyak secara umum. Serta perlu dipertimbangkan untuk memperbarui perlengkapan lab yang dirasa kuno menjadi perlengkapan dengan teknologi terbaru sehingga dapat meningkatkan kualitas layanan pada pasien.
\end{abstract}

Kata Kunci : strategi bersaing, IFE, EFE, Matriks SWOT, Matriks IE, QSPM.

\begin{abstract}
Along with the trends of healthy lifestyle in which many people are attentive with their own medical condition, public become more actively check their health. Especially there is Covid19 pandemic in the present time. Medical check-up can be served by clinical laboratory. This research was performed in Meditest clinical laboratory, located in the city of Semarang. The purpose of this research aims to formulate competitive strategy for Meditest based on definition by Fred $R$. David. The data used on this research is primary type, gathered by interviewing those responsible to Meditest's operational activity, such as owner of Meditest, manager, procurement division, marketing division, and lab analyst. Then, the data is processed, beginning from first step using external factor analysis and internal factor analysis, next steps are IE matrix and SWOT matrix, and the final step is QSPM. Result of the research shows that the suitable strategy that can be used by Meditest is market penetration. Marketing and promotion need to be more intense and frequently, especially using popular social media platform so that it makes Meditest to be more known by general public. Also, need to be considered to update several lab equipments that felt dated, replaced with equipments with latest technology, so that those will improve service quality to patients.
\end{abstract}

Keywords: competitive strategy, IFE, EFE, SWOT Matrix, IE Matrix, QSPM. 
Praxis : Jurnal Sains, Teknologi, Masyarakat dan Jejaring | Vol. 4 | No. 1 | September 2021

\section{PENDAHULUAN}

Layanan kesehatan merupakan salah satu bentuk usaha yang tetap dibutuhkan oleh masyarakat hingga saat ini. Salah satu jenis fasilitas layanan kesehatan tersebut adalah laboratorium kesehatan atau laboratorium klinik. Masyarakat modern umumnya memiliki kesadaran yang tinggi akan gaya hidup sehat, sehingga hal ini mendorong mereka untuk memeriksakan kondisi kesehatan di laboratorium klinik lalu berkonsultasi dengan dokter. Bentuk layanan yang diberikan oleh laboratorium klinik yaitu pemeriksaan kesehatan pada pelanggan atau pasien dengan mengambil sampel dari mereka. Dari hasil pemeriksaan tersebut, pasien yang bersangkutan akan dipanggil oleh dokter yang bertugas untuk konsultasi. Pemeriksaan kesehatan ini bisa disebut sebagai medical check-up. Fungsi-fungsi yang dilakukan oleh laboratorium klinik adalah skrining, diagnosis, pemantauan progresivitas penyakit, monitor pengobatan, dan prognosis penyakit (Purnawati, 2013)

Pengelolaan laboratorium klinik di Indonesia diatur dalam Peraturan Menteri Kesehatan (Permenkes) No. 411 Tahun 2010 tentang Laboratorium Klinik. Dalam Permenkes ini juga dijabarkan bahwa laboratorium klinik dapat dikelola oleh pemerintah atau swasta. Pada laboratorium klinik swasta, seluruh aspek dari permodalan, konsep, dan operasional harus ditanggung sendiri. Pengelola laboratorium klinik swasta harus bersaing satu sama lain dalam memberikan pelayanan terbaik kepada pasien, serta harus berupaya untuk bisa unggul dari pesaing-pesaingnya, salah satu caranya adalah melakukan perumusan strategi. David (2011: 324) mengemukakan tahapan-tahapan perumusan strategi dari (1) input, (2) pencocokan, dan (3) keputusan. Tahap input yaitu dengan melakukan identifikasi peluang dan ancaman eksternal ke dalam matriks evaluasi faktor eksternal (EFE matrix), serta kekuatan dan kelemahan internal ke matriks evaluasi faktor internal (IFE matrix) dari perusahaan yang bersangkutan. Semua faktor yang telah diidentifikasi akan masuk ke tahap pencocokan yang akan menghasilkan beragam alternatif strategi. Terakhir, pada tahap keputusan akan dibuat pilihan final dari sejumlah alternatif strategi tersebut (David, 2011: 324).

Penelitian ini dilakukan pada laboratorium klinik Meditest yang berlokasi di kota Semarang, tepatnya di Jalan Admodirono Raya nomor 6. Pada awalnya, laboratorium klinik ini didirikan pada tahun 1988 dengan nama Medica di jalan Ahmad Yani 137 hingga selanjutnya pada 1999 berganti nama menjadi Meditest sampai saat ini. Pada akhir 2004, Meditest telah berpindah lokasi ke jalan Admodirono Raya 6. Meditest melayani pemeriksaan kesehatan (medical check-up) pada kalangan perorangan dan perusahaan, menggunakan sampel darah, urine, sputum, sekret, dan sperma. Selain itu juga melayani analisis ultrasonografi (USG) dan rontgen foto. Untuk pelanggan dari perusahaan, pemeriksaan kesehatan dilakukan pada pegawai dan calon pegawai dari perusahaan yang bersangkutan untuk mengetahui kondisi dan kelayakan mereka dalam menjalankan pekerjaan. Dari hasil pemeriksaan, pasien juga bisa mendapatkan layanan rawat jalan. Konsumen dalam layanan pemeriksaan ini tidak hanya yang sedang terkena penyakit, tetapi juga ada orang-orang yang berkondisi sehat yang ingin memeriksakan diri ke laboratorium klinik karena perkembangan gaya hidup modern, tuntutan pekerjaan, dan meningkatnya kesadaran diri untuk memeriksakan kondisi kesehatan.

Pesaing Meditest yang berada di Semarang adalah Ideal, Kualita Medika, IBL, dan Sarana Medika. Keempat laboratorium klinik ini memiliki harga dan layanan yang serupa dengan Meditest. 
Praxis : Jurnal Sains, Teknologi, Masyarakat dan Jejaring | Vol. 4 | No. 1 | September 2021

Selain keberadaan laboratorium klinik pesaing, diberlakukannya kebijakan pemerintah berupa program BPJS Kesehatan juga diduga memengaruhi kunjungan pasien ke Meditest. Pengelola Meditest mengungkapkan bahwa setelah pemberlakuan BPJS Kesehatan, kunjungan pasien mengalami penurunan terutama dari kalangan perorangan, karena orang-orang yang terdaftar BPJS lebih memilih fasilitas kesehatan yang juga terdaftar di program BPJS. Namun Meditest masih bisa mengandalkan pemasukan dari kalangan perusahaan atau korporat yang ingin memeriksakan kondisi kesehatan calon karyawan atau karyawan tetapnya.

Penurunan jumlah pasien membuat pengelola laboratorium-laboratorium klinik harus melakukan cara-cara agar tetap dapat menarik minat pelanggan untuk memeriksakan kesehatan di tempatnya, misalnya dengan menurunkan harga produk jasa, bahkan di bawah harga wajar. Pengelola laboratorium klinik pesaing juga ada yang mengirimkan petugasnya berkeliling dalam kompleks pemukiman untuk menawarkan layanan pemeriksaan dari rumah ke rumah sehingga menarik minat penduduk. Ancaman lain juga datang dari apotek-apotek dan bahkan malmal yang turut mengadakan layanan pemeriksaan kesehatan setingkat klinik pratama.

Pada tahun 2020, terjadi pandemi virus korona (Covid-19) di seluruh dunia yang memiliki dampak sangat besar dan menyebabkan krisis multidimensi, mulai dari kesehatan, ekonomi, hingga politik (Afrianto, 2020). Penyedia layanan kesehatan, seperti rumah sakit, laboratorium klinik, dan apotik juga terkena dampak pandemi ini. Masyarakat enggan untuk datang ke rumah sakit atau laboratorium kesehatan. Meditest juga salah satu yang terdampak pandemi. Pasien yang mayoritas merupakan pelanggan setia Meditest enggan keluar rumah termasuk datang untuk periksa ke lab karena takut tertular. Selanjutnya, perusahaanperusahaan yang turut menggunakan jasa Meditest untuk periksa kesehatan para calon karyawan, memutuskan untuk lebih sedikit menerima atau bahkan tidak menerima karyawan baru, dan ini juga berakibat ke menurunnya jumlah pasien yang periksa. Namun dalam pandemi ini Meditest masih mendapat peluang yaitu mengadakan rapid swab test korona dan vaksinasi PCV (pneumococcal conjugate vaccine), untuk menghindari infeksi bakteri pneumokokus yang menyebabkan penyakit pneumonia, meningitis, dan otitis media. Ketiga penyakit ini berhubungan dengan pernapasan dan otak, jadi diharapkan vaksin ini dapat memperkuat daya tahan tubuh di masa pandemi.

Meditest sebenarnya sudah menjalankan beberapa strategi untuk menarik minat pelanggan, misalnya dengan membuat promo berupa paket sederhana dan paket hemat untuk pemeriksaan kesehatan yang selanjutnya ditambah dengan konsultasi gratis dengan dokter sehubungan dengan pemeriksaan tersebut. Selain promo, Meditest juga mengadakan seminar penyuluhan tentang kesehatan yang dilakukan di perusahaan-perusahaan yang bertujuan mendorong orang-orang yang menghadiri seminar itu untuk sadar dan mau melakukan pemeriksaan kesehatan. Dan pada saat pandemi Covid19 ini, Meditest memberikan penawaran kepada pelanggan setia untuk pengambilan sampel darah di rumah pasien masingmasing. Tetapi penawaran tersebut mayoritas ditolak karena mereka juga enggan menerima tamu dari luar rumah demi tidak tertular virus korona. Jadi serangkaian strategi yang selama ini dijalankan masih belum membendung penurunan jumlah pasien. Manajemen dalam Meditest juga belum memiliki sistem yang terstruktur dan masih menggunakan cara tradisional sehingga proses pengambilan keputusan dirasa tidak begitu efektif. Oleh karena itu penelitian ini dilaksanakan agar dapat menemukan 
Praxis : Jurnal Sains, Teknologi, Masyarakat dan Jejaring | Vol. 4 | No. 1 | September 2021

alternatif strategi terbaik yang diharapkan dapat menjawab permasalahan yang dialami Meditest.

\section{Tujuan Penelitian}

Merumuskan dan menentukan strategi bersaing yang tepat untuk laboratorium klinik Meditest Semarang.

\section{Manfaat Penelitian}

Secara teoritis, manfaat penelitian ini adalah sebagai referensi ilmiah untuk penelitian berikutnya tentang perumusan strategi dan manajemen laboratorium klinik. Sedangkan secara praktis, hasil penelitian ini diharapkan menjadi pedoman strategi bersaing pada laboratorium klinik Meditest Semarang, serta sebagai bahan pengetahuan untuk manajemen strategi pada laboratorium klinik dan fasilitas layanan kesehatan lain.

\section{LANDASAN TEORI}

\section{Manajemen Strategis}

Menurut David (2011: 5), manajemen strategis adalah bentuk pengetahuan yang digunakan untuk merumuskan, mengimplementasikan, dan mengevaluasi berbagai keputusan yang akan dilakukan suatu organisasi dalam mencapai tujuan. Ada tiga tahapan dalam manajemen strategis, yaitu perumusan strategi, penerapan strategi, dan penilaian strategi. Namun, oleh Hunger \& Wheelen (2003: 45), ada satu tahap lagi sebelum ketiga tahap tersebut, yaitu pengamatan lingkungan. Menurutnya, manajemen strategis menekankan pada pengamatan serta evaluasi peluang dan ancaman lingkungan sekitar berdasarkan kekuatan dan kelemahan yang dimiliki perusahaan. Jadi, total ada empat tahap dalam manajemen strategis.
1) Pengamatan lingkungan, yaitu manajemen mengamati peluang dan ancaman dari lingkungan eksternal serta mengidentifikasi kekuatan dan kelemahan dari lingkungan internal perusahaan, yang kemudian disebut sebagai faktor-faktor strategis dan diringkas menjadi SWOT (strengths kekuatan, weaknesses - kelemahan, opportunities - peluang, threats ancaman).

2) Perumusan (formulasi) terdiri dari pengembangan visi dan misi yang menjadi dasar untuk penetapan tujuan jangka panjang, pertimbangan strategi alternatif, hingga keputusan memilih strategi tertentu agar dapat mencapai tujuan.

3) Penerapan (implementasi), merupakan tahap penerapan strategi yang telah dipilih perusahaan dalam bentuk program, anggaran, dan prosedur. Perusahaan harus menetapkan tujuan tahunan dan mengalokasikan sumber daya yang dimiliki agar tujuan bisa tercapai.

4) Penilaian (evaluasi) merupakan bentuk evaluasi dari strategi yang telah dilaksanakan, untuk mengetahui apakah strategi tersebut dapat berjalan dengan baik. Strategi dapat diubah dalam tahap ini karena keadaan internal dan eksternal perusahaan yang selalu berubah-ubah.

Jadi, dari paparan kedua ahli bahwa dalam manajemen strategis, patut diawali dengan menetapkan tujuan, yaitu ingin menjadi seperti apa. Lalu memperhatikan keadaan internal dan eksternal diri sendiri. Menerapkan strategi sebaiknya menyesuaikan dengan sumber daya yang dimiliki, dan yang tidak boleh terlewatkan yaitu melakukan evaluasi strategi untuk memastikan tujuan benar-benar tercapai. 
Praxis : Jurnal Sains, Teknologi, Masyarakat dan Jejaring | Vol. 4 | No. 1 | September 2021

\section{Strategi Bersaing}

David (2011: 248-249) mengelompokkan jenis-jenis strategi yang dapat digunakan suatu perusahaan untuk menghadapi persaingan dengan perusahaan lain. Terdapat sebelas (11) jenis strategi yang dikelompokkan menjadi empat kelompok besar strategi yaitu strategi integratif, strategi intensif, strategi diversifikasi, dan strategi defensif.

\section{Pengamatan Lingkungan Eksternal}

Lingkungan eksternal menurut Hunger \& Wheelen (2003: 9-10) adalah variabelvariabel yang berada di luar organisasi dan biasanya tidak dalam jangkauan kendali jangka pendek dari manajemen puncak. Lingkungan eksternal terbagi menjadi lingkungan kerja dan lingkungan sosial.

\section{Pengamatan Lingkungan Internal}

Lingkungan internal menurut Hunger \& Wheelen (2003: 11-12) terdiri dari variabel-variabel yang ada di dalam organisasi namun biasanya tidak dalam pengendalian jangka pendek dari manajemen puncak. Variabel ini meliputi struktur, budaya, dan sumber daya organisasi. Variabel-variabel internal di atas kemudian dapat dioptimalkan dan dipadukan oleh manajemen strategis yang selanjutnya membantu sebuah organisasi memiliki keunggulan kompetitif dibandingkan organisasi lainnya.

\section{Analisis SWOT}

SWOT merupakan akronim dari kata strength (kekuatan) dan weakness (kelemahan) dari lingkungan internal perusahaan serta opportunity (peluang) dan threat (ancaman) dari lingkungan eksternal perusahaan. Keempat faktor di atas selanjutnya dapat digunakan sebagai dasar analisis strategi. Analisis SWOT menurut Pearce II \& Johnson Jr., (2013: 156-158) adalah sebuah teknik di mana manajer menciptakan gambaran umum secara cepat mengenai keadaan strategis perusahaan, berdasarkan pada kesesuaian yang baik antara sumber daya internal (kekuatan dan kelemahan) dengan keadaan eksternal perusahaan (peluang dan ancaman). Strategi akan berjalan dengan efektif apabila manajemen dapat memaksimalkan kekuatan dan peluang perusahaan serta meminimalkan kelemahan dan ancaman pada perusahaan. Berikut di bawah ini adalah penjelasan masing-masing dari keempat faktor.

1. Peluang, merupakan suatu situasi yang memiliki kecenderungan menguntungkan pada lingkungan luar perusahaan. Misalnya identifikasi segmen pasar, perubahan regulasi, perubahan keadaan persaingan, hingga hubungan dengan pembeli dan pemasok.

2. Ancaman, merupakan situasi utama yang tidak menguntungkan pada lingkungan luar perusahaan, karena menjadi penghalang utama bagi perusahaan dalam mencapai tujuan atau posisi yang diinginkan. Ancaman bisa berupa perubahan regulasi, masuknya pesaing baru, dan meningkatnya kemampuan tawarmenawar dari pembeli dan pemasok.

3. Kekuatan, merupakan sumber daya, kemampuan, dan kompetensi yang dimiliki atau dapat dikendalikan oleh suatu perusahaan, yang kemudian dapat membuat perusahaan lebih unggul dari pesaing dalam memenuhi kebutuhan konsumen.

4. Kelemahan, merupakan keterbatasan atau kekurangan dalam sumber daya atau kompetensi suatu perusahaan dibandingkan dengan pesaingnya, yang kemudian menjadi penghalang dalam memenuhi kebutuhan konsumen. 
Praxis : Jurnal Sains, Teknologi, Masyarakat dan Jejaring | Vol. 4 | No. 1 | September 2021

Pearce II \& Johnson Jr. (2013: 158-159) menerangkan bahwa analisis SWOT sering digunakan untuk mengarahkan pembahasan dan refleksi mengenai situasi dan alternatif suatu perusahaan, dan menjadi bagian dari diskusi tingkat manajerial, karena masing-masing manajer bisa jadi memiliki pandangan yang berbeda atas lingkungan perusahaan.

\section{Matriks EFE dan IFE}

Matriks evaluasi faktor eksternal (external factor evaluation - EFE matrix) menurut David (2011: 158) dapat memungkinkan para penyusun strategi untuk melakukan evaluasi faktor peluang dan ancaman dari aspek ekonomi, sosial, budaya, demografi, lingkungan, politik, pemerintahan, hukum, dan teknologi. Setelah faktor-faktor eksternal, evaluasi selanjutnya dilakukan pada bagian internal. David (2011: 229) mengemukakan matriks evaluasi faktor internal (internal factor evaluation - IFE matrix) yang digunakan untuk mengevaluasi kekuatan dan kelemahan fungsional bisnis dari perusahaan.

\section{Matriks Internal-Eksternal (IE)}

\section{Matriks internal-eksternal} menggambarkan posisi suatu perusahaan dalam bentuk sembilan sel. Matriks ini berdasarkan pada nilai hasil dari matriks IFE pada sumbu $x$ dan matriks EFE pada sumbu y. Tingginya nilai pada masingmasing sumbu $\mathrm{x}$ dan $\mathrm{y}$ menunjukkan kekuatan posisi organisasi (David, 2011 : 345). Nilai 1,0 hingga 1,99 menunjukkan posisi organisasi sedang rendah/lemah; nilai 2,0 hingga 2,99 menunjukkan posisi sedang; dan nilai 3,0 hingga 4,0 berarti posisinya tinggi/kuat. Dari sembilan sel dalam matriks IE dibagi menjadi tiga bagian utama yang masing-masing mempunyai implikasi strategi yang berbeda-beda. Divisi yang masuk dalam sel I, II, dan III digambarkan sebagai tumbuh dan membangun; divisi dalam sel III, V, dan VII dapat memakai strategi menjaga dan mempertahankan; terakhir, divisi dalam sel VI, VIII, dan IX dapat memakai strategi panen atau divestasi.

\section{Matriks SWOT}

Matriks SWOT (strengths-weaknessesopportunities-threats) merupakan alat pencocokan strategi yang menggunakan faktor-faktor eksternal dan internal organisasi. Menurut David (2011: 327331) dari alat pencocokkan ini akan menghasilkan empat macam strategi yaitu:

1) Strategi SO (kekuatan-peluang), yang memanfaatkan kekuatan internal perusahaan untuk mendapatkan keuntungan dari peluang eksternal.

2) Strategi WO (kelemahan-peluang), yang digunakan untuk memperbaiki kelemahan internal berdasarkan peluang eksernal yang ada.

3) Strategi ST (kekuatan-ancaman), yang menggunakan kekuatan internal perusahaan untuk menghindari atau mengurangi dampak ancaman eksternal.

4) Strategi WT (kelemahan-ancaman), yang dimana perusahaan akan melakukan strategi bertahan untuk mengurangi kelemahan internal dan menghindari ancaman eksternal.

Matriks SWOT terdiri dari sembilan sel yaitu empat sel faktor-faktor utama (eksternal dan internal), empat sel strategi (SO, WO, ST, WT), dan satu sel kosong pada bagian kiri atas.

\section{Matriks Perencanaan Strategi Kuantitatif (QSPM)}

Matriks perencanaan strategi kuantitatif (quantitative strategic planning matrix QSPM) membantu manajer untuk memutuskan strategi apakah yang terbaik dari sejumlah pilihan strategi. David (2011: 350) menjelaskan bahwa QSPM 
Praxis : Jurnal Sains, Teknologi, Masyarakat dan Jejaring | Vol. 4 | No. 1 | September 2021

terdiri dari sebuah tabel, di mana bagian kolom kiri berisikan faktor-faktor eksternal dan internal beserta skor bobot masingmasing faktor yang sudah didapatkan dari tahap 1 (input) yaitu dari matriks IFE dan EFE. Selanjutnya bagian baris atas dari QSPM berisi macam-macam strategi alternatif dari tahap 2 (pencocokan). Tidak semua alternatif strategi yang muncul di tahap pencocokan bisa dimasukkan ke QSPM, pembuat strategi harus melakukan seleksi dulu, manakah strategi yang paling layak dan masuk akal untuk dapat dipertimbangkan dalam QSPM.

Komponen-komponen dalam QSPM di antaranya adalah: alternatif-alternatif strategi; faktor-faktor utama; bobot; skor daya tarik (attractiveness score - AS); skor daya tarik total (total attractiveness score TAS); dan jumlah keseluruhan daya tarik total (sum total attractiveness score STAS).

\section{Kerangka Pikir}

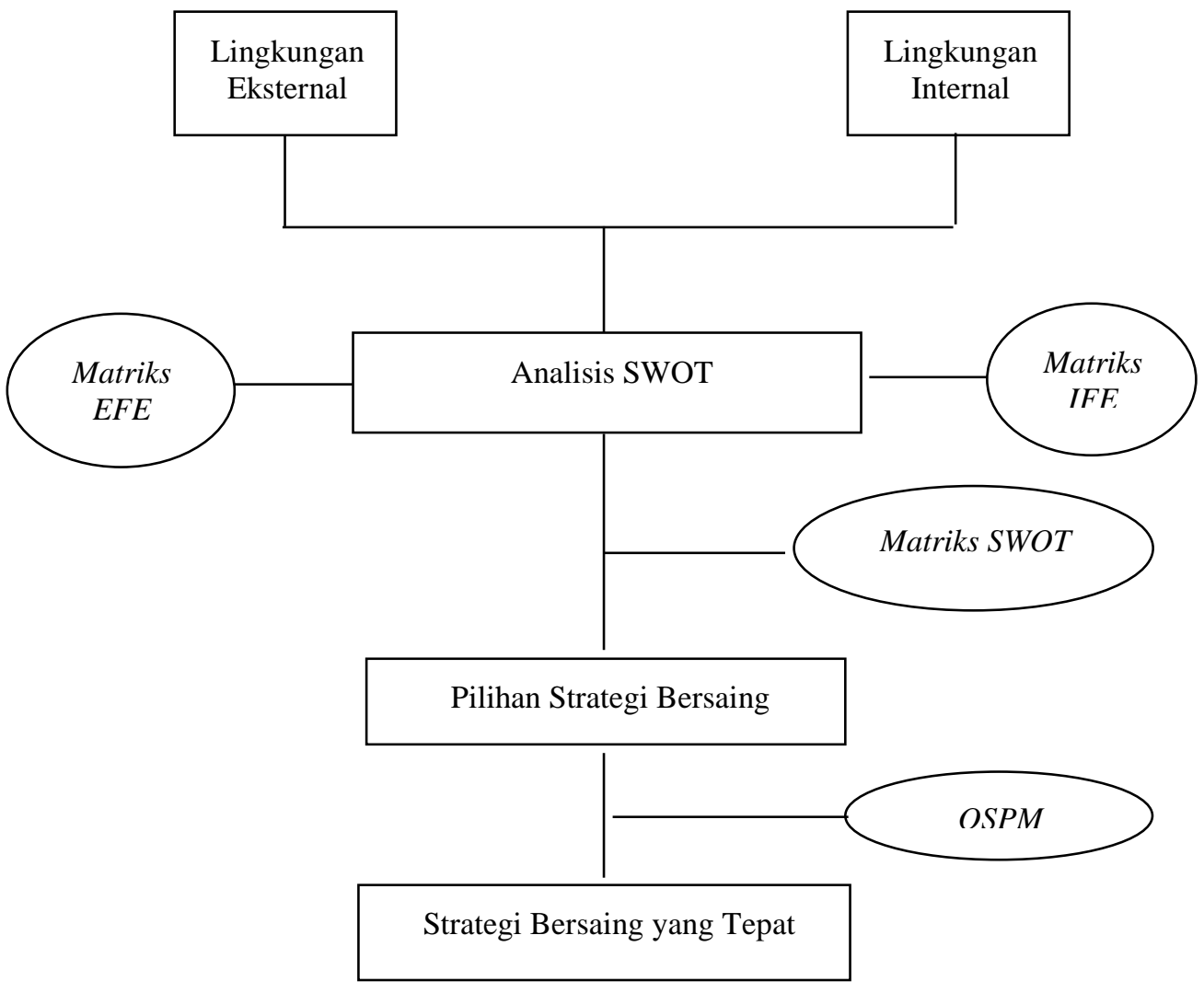

Gambar 1. Kerangka Pikir

\section{Definisi Operasional}

1) Lingkungan eksternal, adalah faktorfaktor atau keadaan yang berada di luar kendali perusahaan, terdiri dari peluang dan ancaman yang harus dihadapi perusahaan. Indikatornya adalah teknologi informasi dan komunikasi, teknologi kesehatan, relasi dengan pihak luar (konsumen, pesaing, mitra kerja).

2) Lingkungan internal, adalah faktorfaktor yang sedang dimiliki oleh perusahaan dan masih dalam kendali, berupa kekuatan dan kelemahan. Indikatornya adalah pelayanan konsumen, prosedur kerja, lokasi, pengelolaan bahan baku. 
Praxis : Jurnal Sains, Teknologi, Masyarakat dan Jejaring | Vol. 4 | No. 1 | September 2021

3) Pilihan strategi, yang didapat dari hasil identifikasi dan pencocokan faktorfaktor internal dan eksternal melalui matriks SWOT.

4) Strategi bersaing yang tepat, merupakan keputusan akhir strategi yang paling sesuai dengan menganalisis semua alternatif strategi yang muncul di tahap sebelumnya melalui matriks perencanaan strategi kuantitatif (QSPM).

\section{METODE PENELITIAN}

Obyek penelitian ini adalah Laboratorium Klinik Meditest, sebuah usaha layanan kesehatan berupa laboratorium kesehatan swasta yang berlokasi di jalan Admodirono Raya nomor 6, Semarang. Alasan pemilihan Meditest sebagai obyek penelitian adalah perusahaan ini masih membutuhkan perbaikan dan usulan manajemen agar perusahaan semakin berkembang, apalagi kinerja perusahaan sedang menurun (penurunan kunjungan pasien) serta dalam kondisi pandemi Covid-19 yang dimulai dari tahun 2020 hingga saat ini.

Jenis data yang digunakan dalam penelitian ini adalah data primer dan data sekunder. Data primer, yang merupakan data yang didapatkan langsung dari obyek penelitian, adalah berupa wawancara semistruktur dengan orang-orang yang terlibat langsung dalam segala aktivitas di Meditest. Mereka adalah pemilik sekaligus pimpinan, manajer, bagian pembelian, bagian pemasaran, dan analis laboratorium. Tujuan wawancara adalah untuk mengidentifikasi peluang dan ancaman eksternal serta kekuatan dan kelemahan internal dari Meditest. Data sekunder adalah data tertulis yang sudah diolah, dalam hal ini adalah data kunjungan tahunan Meditest dan daftar harga produk Meditest.
Data dianalisis secara deskriptif kualitatif dan kuantitatif. Metode kualitatif dilakukan dengan cara mewawancara pimpinan dan karyawan sebagai narasumber, sedangkan metode kuantitatif dengan cara analisis matriks EFE dan IFE, matriks IE, dan QSPM. Tahapan kuantitatifnya adalah sebagai berikut.

1. Melakukan analisis lingkungan eksternal menggunakan matriks EFE. Faktor-faktor eksternal yang didapat, masing-masing diberi bobot (B) mulai dari 0,0 hingga 1,0 , di mana bobot menunjukkan tingkat pengaruh faktor dan total jumlah bobot harus sama dengan 1,0 . Selanjutnya rating $(\mathrm{R})$ dari 1 hingga 4 diberikan kepada setiap faktor, dengan 1: ancaman tingkat serius; 2: ancaman mudah; 3: peluang biasa; dan 4: peluang yang harus segera dimanfaatkan. Bobot (B) dan rating (R) masing-masing faktor kemudian dikalikan, lalu dijumlahkan semua sehingga muncul nilai total matriks EFE.

2. Melakukan analisis lingkungan internal menggunakan matriks IFE. Faktor-faktor internal yang didapat, masing-masing diberi bobot (B) mulai dari 0,0 hingga 1,0 , di mana bobot menunjukkan tingkat pengaruh faktor dan total jumlah bobot harus sama dengan 1,0 . Selanjutnya rating $(\mathrm{R})$ dari 1 hingga 4 diberikan kepada setiap faktor, di mana rating menunjukkan seberapa lemah atau seberapa kuat sebuah perusahaan dibandingkan dengan pesaingnya. Faktor kekuatan memiliki nilai $\mathrm{R}$ sebesar 3 atau 4, sedangkan faktor kelemahan memiliki nilai $R$ sebeser 1 atau 2. Bobot (B) dan rating (R) masing-masing faktor kemudian dikalikan, lalu dijumlahkan semua sehingga muncul nilai total matriks IFE.

3. Nilai total matriks EFE dan IFE kemudian ditafsirkan ke dalam matriks 
Praxis : Jurnal Sains, Teknologi, Masyarakat dan Jejaring | Vol. 4 | No. 1 | September 2021

IE, yang menggambarkan titik temu antara sumbu $\mathrm{x}$ (total nilai IFE) dengan sumbu y (total nilai EFE).

4. Matriks SWOT: Masing-masing faktor yaitu peluang dan ancaman dari lingkungan eksternal serta kekuatan dan kelemahan dari lingkungan internal, dicocokkan satu sama lain sehingga terbentuk empat jenis strategi yaitu strategi SO (kekuatan-peluang), WO (kelemahan-peluang), ST (kekuatan-ancaman), dan WT (kelemahan-ancaman).

5. QSPM: Strategi dari matriks SWOT kemudian akan disandingkan dengan faktor-faktor dari matriks EFE dan matriks IFE berdasarkan skor daya tarik (AS) masing-masing faktor. AS akan dikalikan dengan bobot masingmasing faktor, menghasilkan total skor daya tarik (TAS).

\section{HASIL DAN PEMBAHASAN}

\section{Lingkungan Eksternal Perusahaan}

Dari hasil wawancara kepada narasumber, dapat dijabarkan faktor-faktor eksternal sebagai berikut. a. Peluang

1) Hubungan baik dengan laboratorium klinik lainnya

2) Hubungan baik dengan pelanggan, khususnya pelanggan setia

3) Penggunaan teknologi informasi

4) Penyuluhan tentang kesehatan dan vaksinasi

b. Ancaman

1) Persaingan ketat antar laboratorium klinik

2) Kebijakan pemerintah berupa BPJS Kesehatan

3) Apotek dan mal yang juga menyediakan layanan pemeriksaan kesehatan

4) Laboratorium klinik lainnya saling menurunkan harga paket pemeriksaan

5) Kesadaran masyarakat untuk periksa kesehatan masih rendah

Tabel matriks EFE adalah sebagai berikut.

Tabel 1. Matriks EFE - Laboratorium Klinik Meditest

\begin{tabular}{|l|c|c|c|}
\hline Faktor-faktor Eksternal Utama & Bobot & Peringkat & Skor Bobot \\
\hline Peluang & \multicolumn{2}{|l|}{} \\
\hline $\begin{array}{l}\text { 1.Hubungan baik dengan laboratorium klinik } \\
\text { lainnya }\end{array}$ & 0,11 & 4 & 0,44 \\
\hline $\begin{array}{l}\text { 2.Hubungan baik dengan pelanggan, khususnya } \\
\text { pelanggan setia }\end{array}$ & 0,13 & 4 & 0,50 \\
\hline 3.Penggunaan teknologi informasi & 0,13 & 4 & 0,50 \\
\hline 4.Penyuluhan tentang kesehatan dan vaksinasi & 0,11 & 4 & 0,44 \\
\hline Ancaman & & & \\
\hline 1.Persaingan ketat antar laboratorium klinik & 0,12 & 2 & 0,24 \\
\hline 2.Kebijakan pemerintah berupa BPJS Kesehatan & 0,12 & 1 & 0,12 \\
\hline
\end{tabular}


Praxis : Jurnal Sains, Teknologi, Masyarakat dan Jejaring | Vol. 4 | No. 1 | September 2021

\begin{tabular}{|l|c|c|c|}
\hline Faktor-faktor Eksternal Utama & Bobot & Peringkat & Skor Bobot \\
\hline Peluang & \multicolumn{2}{l|}{} \\
\hline $\begin{array}{l}\text { 3.Apotek dan mal yang juga menyediakan } \\
\text { layanan pemeriksaan kesehatan }\end{array}$ & 0,08 & 2 & 0,16 \\
\hline $\begin{array}{l}\text { 4.Laboratorium klinik lainnya saling } \\
\text { menurunkan harga paket pemeriksaan }\end{array}$ & 0,11 & 2 & 0,22 \\
\hline $\begin{array}{l}\text { 5.Kesadaran masyarakat untuk periksa } \\
\text { kesehatan masih rendah }\end{array}$ & 0,10 & 2 & 0,21 \\
\hline Total & $\mathbf{1 , 0 0}$ & & $\mathbf{2 , 8 2}$ \\
\hline
\end{tabular}

Sumber: Data primer yang diolah (2020)

Dari penghitungan dalam matriks EFE dihasilkan nilai 2,82 dimana kemampuan Meditest dalam merespons keadaankeadaan eksternal adalah sedang.

\section{Lingkungan Internal Perusahaan}

Hasil wawancara kepada narasumber memaparkan faktor-faktor internal sebagai berikut.

a. Kekuatan

1) Pelayanan yang ramah kepada pelanggan

2) Lokasi yang strategis
3) Harga yang bersaing

4) Hasil pemeriksaan yang akurat

5) Ruangan yang bersih dan nyaman

6) Bahan-bahan reagen dikelola dengan baik

b. Kelemahan

1) Beberapa jenis pemeriksaan yang sepi peminat tidak dapat dilakukan

2) Suasana ruang tunggu yang datar karena fasilitas hiburannya sedikit

Tabel matriks IFE adalah sebagai berikut.

Tabel 2. Matriks IFE - Laboratorium Klinik Meditest

\begin{tabular}{|c|c|c|c|}
\hline Faktor-faktor Internal Utama & Bobot & Peringkat & Skor Bobot \\
\hline \multicolumn{4}{|l|}{ Kekuatan } \\
\hline 1.Pelayanan yang ramah kepada pelanggan & 0,13 & 4 & 0,53 \\
\hline 2.Lokasi yang strategis & 0,12 & 3 & 0,35 \\
\hline 3.Harga yang bersaing & 0,12 & 3 & 0,37 \\
\hline 4.Hasil pemeriksaan yang akurat & 0,14 & 4 & 0,56 \\
\hline 5. Ruangan yang bersih dan nyaman & 0,14 & 3 & 0,42 \\
\hline 6.Bahan-bahan reagen dikelola dengan baik & 0,14 & 3 & 0,42 \\
\hline \multicolumn{4}{|l|}{ Kelemahan } \\
\hline $\begin{array}{l}\text { 1.Beberapa jenis pemeriksaan yang sepi } \\
\text { peminat tidak dapat dilakukan }\end{array}$ & 0,09 & 2 & 0,19 \\
\hline
\end{tabular}


Praxis : Jurnal Sains, Teknologi, Masyarakat dan Jejaring | Vol. 4 | No. 1 | September 2021

\begin{tabular}{|l|c|c|c|}
\hline $\begin{array}{c}\text { 2.Suasana ruang tunggu yang datar karena } \\
\text { fasilitas hiburannya sedikit }\end{array}$ & 0,12 & 1 & 0,12 \\
\hline Total & $\mathbf{1 , 0 0}$ & & $\mathbf{2 , 9 5}$ \\
\hline
\end{tabular}

Sumber: Data primer yang diolah (2020)

Dari hasil penghitungan matriks IFE Meditest memiliki total nilai 2,95, dengan demikian Meditest berada dalam posisi sedang.

\section{Matriks Internal - Eksternal (IE)}

Posisi eksternal Meditest yang dihitung menggunakan matriks EFE menghasilkan total nilai 2,82, sementara posisi internalnya menggunakan matriks IFE total nilainya adalah 2,95. Kedua jenis nilai dipertemukan dalam matriks internaleksternal (IE).

Tabel 3. Matriks IE - Laboratorium Klinik Meditest

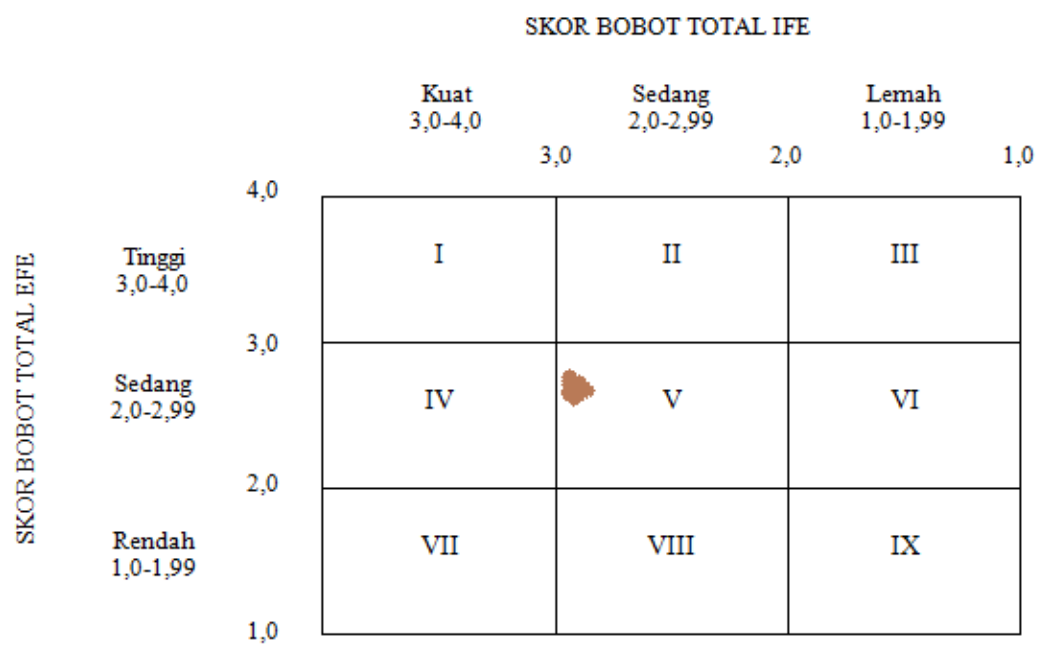

Hasil pertemuan tersebut menunjukkan bahwa Meditest terletak dalam kuadran V, di mana termasuk dalam kategori menjaga dan mempertahankan (hold and maintain), sehingga jenis strategi yang tepat menurut David (2011 : 345) adalah penetrasi pasar dan pengembangan produk

\section{Matriks SWOT}

Setelah ditemukan faktor-faktor eksternal dan internal pada Meditest, selanjutnya akan dibuat matriks SWOT yang isinya adalah menyandingkan masing-masing faktor tersebut untuk menghasilkan alternatif strategi. Di mana alternatif strategi tersebut akan disesuaikan dengan posisi Meditest dalam matriks IE, yaitu kuadran $\mathrm{V}$ yang berarti jenis strateginya adalah menjaga dan mempertahankan. 
Praxis : Jurnal Sains, Teknologi, Masyarakat dan Jejaring | Vol. 4 | No. 1 | September 2021

\begin{tabular}{|c|c|c|}
\hline & $\begin{array}{l}\text { Kekuatan (Strength - S) } \\
\text { 1.Pelayanan yang ramah } \\
\text { kepada pelanggan } \\
\text { 2.Lokasi yang strategis } \\
\text { 3.Harga yang bersaing } \\
\text { 4.Hasil pemeriksaan yang } \\
\text { akurat } \\
\text { 5.Ruangan yang bersih dan } \\
\text { nyaman } \\
\text { 6.Bahan-bahan reagen dikelola } \\
\text { dengan baik }\end{array}$ & $\begin{array}{l}\text { Kelemahan (Weakness - W) } \\
\text { 1.Beberapa jenis pemeriksaan } \\
\text { yang sepi peminat } \\
\text { tidak dapat dilakukan } \\
\text { 2.Suasana ruang tunggu yang } \\
\text { datar karena fasilitas } \\
\text { hiburannya sedikit }\end{array}$ \\
\hline $\begin{array}{l}\text { Peluang (Opportunity - O) } \\
\text { 1.Hubungan baik dengan } \\
\text { laboratorium klinik lainnya } \\
\text { 2.Hubungan baik dengan } \\
\text { pelanggan, khususnya } \\
\text { pelanggan setia } \\
\text { 3.Penggunaan teknologi } \\
\text { informasi } \\
\text { 4.Penyuluhan tentang } \\
\text { kesehatan dan vaksinasi }\end{array}$ & $\begin{array}{l}\text { Strategi SO (Strength- } \\
\text { Opportunity) } \\
\text { 1.Memberikan layanan yang } \\
\text { tanggap dan ramah pada } \\
\text { konsumen } \\
\text { 2.Melakukan promosi lebih } \\
\text { gencar melalui media sosial } \\
\text { 3.Selalu mengingatkan pasien } \\
\text { untuk pemeriksaan berikutnya, } \\
\text { serta memberikan promo } \\
\text { khusus melalui whatsapp }\end{array}$ & $\begin{array}{l}\text { Strategi WO (Weakness- } \\
\text { Opportunity) } \\
\text { 1.Memperkuat kerja sama } \\
\text { dengan laboratorium klinik lain } \\
\text { untuk rujukan pasien } \\
\text { 2.Membuka pemesanan } \\
\text { melalui whatsapp dari jauh hari } \\
\text { untuk pemeriksaan tertentu } \\
\text { yang jarang dilakukan }\end{array}$ \\
\hline $\begin{array}{l}\text { Ancaman (Threat - T) } \\
\text { 1.Persaingan yang ketat } \\
\text { antar laboratorium klinik } \\
\text { 2.Kebijakan pemerintah } \\
\text { berupa BPJS Kesehatan } \\
\text { 3.Apotek dan mal yang juga } \\
\text { menyediakan layanan } \\
\text { pemeriksaan kesehatan } \\
\text { 4.Laboratorium klinik } \\
\text { lainnya saling menurunkan } \\
\text { harga paket pemeriksaan } \\
\text { 5.Kesadaran masyarakat } \\
\text { untuk periksa kesehatan } \\
\text { masih rendah }\end{array}$ & $\begin{array}{l}\text { Strategi ST (Strength- } \\
\text { Threat) } \\
\text { 1.Mengadakan promo namun } \\
\text { dengan harga layanan yang } \\
\text { wajar dan tidak terlalu banting } \\
\text { harga. } \\
\text { 2.Memberikan penyuluhan } \\
\text { kesehatan atau tips tentang } \\
\text { permasalahan kesehatan } \\
\text { misalnya kanker serviks. }\end{array}$ & $\begin{array}{l}\text { Strategi WT (Weakness- } \\
\text { Threat) } \\
\text { 1.Mempertimbangkan } \\
\text { peremajaan peralatan lab } \\
\text { dengan teknologi baru agar } \\
\text { menunjang proses lab. }\end{array}$ \\
\hline
\end{tabular}


Praxis : Jurnal Sains, Teknologi, Masyarakat dan Jejaring | Vol. 4 | No. 1 | September 2021

\section{Matriks Perencanaan Strategi Kuantitatif (QSPM)}

\begin{tabular}{|c|c|c|c|c|c|}
\hline \multirow{3}{*}{$\begin{array}{l}\text { Faktor-faktor kunci } \\
\end{array}$} & \multirow[b]{3}{*}{ Bobot } & \multirow{2}{*}{\multicolumn{2}{|c|}{\begin{tabular}{|l|} 
Strategi I \\
Penetrasi pasar \\
\end{tabular}}} & \multirow{2}{*}{\multicolumn{2}{|c|}{$\begin{array}{l}\text { Strategi II } \\
\begin{array}{l}\text { Pengembangan } \\
\text { produk }\end{array}\end{array}$}} \\
\hline & & & & & \\
\hline & & $\mathbf{A S}$ & TAS & $\mathbf{A S}$ & TAS \\
\hline \multicolumn{6}{|l|}{ Kekuatan } \\
\hline Pelayanan yang ramah pada pelanggan & 0,13 & 4 & 0,53 & 1 & 0,13 \\
\hline Lokasi yang strategis & 0,12 & 3 & 0,35 & 2 & 0,23 \\
\hline Harga yang bersaing & 0,12 & 3 & 0,37 & 1 & 0,12 \\
\hline Hasil pemeriksaan yang akurat & 0,14 & 4 & 0,56 & 2 & 0,28 \\
\hline Ruangan yang bersih dan nyaman & 0,14 & 3 & 0,42 & 2 & 0,28 \\
\hline Bahan-bahan reagen dikelola dengan baik & 0,14 & 2 & 0,28 & 2 & 0,28 \\
\hline \multicolumn{6}{|l|}{ Kelemahan } \\
\hline $\begin{array}{l}\text { Beberapa jenis pemeriksaan yang sepi peminat } \\
\text { tidak dapat dilakukan }\end{array}$ & 0,09 & 2 & 0,19 & 4 & 0,37 \\
\hline $\begin{array}{l}\text { Suasana ruang tunggu yang datar karena } \\
\text { fasilitas hiburannya sedikit }\end{array}$ & 0,12 & 2 & 0,23 & 2 & 0,23 \\
\hline \multicolumn{6}{|l|}{ Peluang } \\
\hline $\begin{array}{l}\text { Hubungan baik dengan fasilitas kesehatan } \\
\text { lainnya }\end{array}$ & 0,11 & 3 & 0,33 & 2 & 0,22 \\
\hline $\begin{array}{l}\text { Hubungan baik dengan pelanggan, khususnya } \\
\text { pelanggan setia }\end{array}$ & 0,13 & 3 & 0,38 & 2 & 0,25 \\
\hline Penggunaan teknologi informasi & 0,13 & 4 & 0,50 & 2 & 0,25 \\
\hline Penyuluhan tentang kesehatan dan vaksinasi & 0,11 & 2 & 0,22 & 2 & 0,22 \\
\hline \multicolumn{6}{|l|}{ Ancaman } \\
\hline Persaingan ketat antar laboratorium klinik & 0,12 & 3 & 0,35 & 3 & 0,35 \\
\hline Kebijakan pemerintah berupa BPJS Kesehatan & 0,12 & 2 & 0,24 & 2 & 0,24 \\
\hline $\begin{array}{l}\text { Apotek dan mal yang menyediakan layanan } \\
\text { pemeriksaan kesehatan }\end{array}$ & 0,08 & 2 & 0,16 & 3 & 0,24 \\
\hline 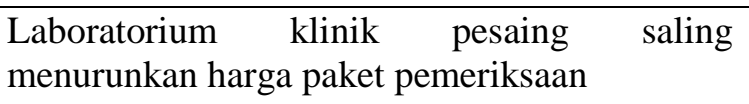 & 0,11 & 3 & 0,33 & 2 & 0,22 \\
\hline $\begin{array}{l}\text { Kesadaran masyarakat untuk periksa kesehatan } \\
\text { masih rendah }\end{array}$ & 0,10 & 1 & 0,10 & 1 & 0,10 \\
\hline STAS & & & 5,53 & & 4,03 \\
\hline
\end{tabular}

Keterangan:

- AS: attractiveness score - skor daya tarik. Skor ini diberikan ke masingmasing faktor untuk menunjukkan tingkat pengaruh atau daya tarik faktor akan masing-masing pilihan strategi. Kisaran skor $1 ; 2 ; 3 ; 4$, semakin tinggi 
Praxis : Jurnal Sains, Teknologi, Masyarakat dan Jejaring | Vol. 4 | No. 1 | September 2021

skor maka pengaruh faktor ke strategi makin tinggi.

- TAS: total attractiveness score - skor daya tarik total. Merupakan hasil kali antara Bobot dengan AS (skor daya tarik) di setiap baris. Semakin tinggi skornya maka semakin menarik pula pilihan strategi tersebut.

- STAS: sum total attractiveness score jumlah keseluruhan daya tarik total. Penjumlahan semua TAS masingmasing kolom dari pilihan strategi. Skor yang paling tinggi menunjukkan bahwa pilihan strategi yang terkait menjadi paling menarik.

Berdasarkan analisis yang dilakukan melalui QSPM, jumlah skor tertinggi dalam matriks tersebut terdapat pada strategi penetrasi pasar, dengan tujuan untuk menambah pangsa pasar dari pasar yang sudah dicakup.

Pada faktor Kekuatan, nilai ketertarikan (AS) sebesar 4 yang artinya sangat menarik, diberikan pada pelayanan yang ramah dan hasil pemeriksaan yang akurat. Pemberian skor sangat menarik tersebut dikarenakan pelayanan yang ramah akan memberikan kesan yang baik bagi pelanggan dan merasa nyaman setelah melakukan pemeriksaan di Meditest. Hasil pemeriksaan yang akurat dapat meningkatkan kepercayaan pelanggan pada Meditest. Dengan kesan positif dan kepercayaan pelanggan, diharapkan pelanggan tersebut dapat memeriksakan kembali di Meditest, hingga memberitahu teman dekat atau relasinya untuk juga ikut periksa di Meditest. Sehingga pangsa pasar Meditest diharapkan meningkat, sebagaimana tujuan dari penetrasi pasar. Sementara untuk faktor lokasi yang strategis, harga yang bersaing, serta ruangan yang bersih dan nyaman, mendapatkan skor cukup menarik atau 3. Meditest sendiri terletak di jalan Admodirono Raya, yang dapat diakses sekali belok dari jalan Ahmad Yani di mana jalan tersebut merupakan jalan utama. Di sebelah Meditest terdapat restoran Sendok Bebek serta Gereja Admodirono yang merupakan titik keramaian, sehingga orang-orang yang berkunjung ke dua tempat tersebut diharapkan dengan mudah mengetahui keberadaan Meditest. Faktor harga, masih tetap menjadi penentu seseorang untuk memilih. Tidak terlalu banyak promo harga namun harga masih dapat bersaing dengan laboratorium klinik lain. Bagi yang sudah pernah memeriksakan diri di Meditest akan di-follow up dengan memberikan harga khusus promo serta menanyakan kondisi kesehatannya. Orang yang senang dengan pelayanan Meditest, diharapkan dapat memberitahukan info tentang Meditest kepada orang-orang terdekatnya. Suasana ruang tunggu yang nyaman membuat orang yang menunggu giliran atau hasil pemeriksaan, merasa betah, dan diharapkan bisa periksa lagi di Meditest. Faktor pengelolaan bahan reagen, memang berpengaruh pada efektivitas dan efisiensi layanan, namun mendapatkan nilai 2, karena tidak berdampak signifikan pada preferensi pelanggan.

Pada faktor Kelemahan, nilai ketertarikan sebesar 2 diberikan pada kedua faktor kunci. Faktor beberapa pemeriksaan yang tidak dapat dilakukan serta faktor suasana ruang tunggu, tidak terlalu berdampak pada strategi meningkatkan pangsa pasar. Nilai ketertarikan untuk faktor pemeriksaan yang tidak dapat dilakukan, lebih tinggi pada strategi pengembangan produk di mana membutuhkan pengembangan item pemeriksaan baru.

Pada faktor Peluang, hubungan baik dengan fasilitas kesehatan lain serta hubungan baik dengan pelanggan mendapatkan nilai 3. Menjalin hubungan yang baik kepada laboratorium klinik pesaing dan penyedia layanan kesehatan lain, dapat memungkinkan Meditest untuk 
Praxis : Jurnal Sains, Teknologi, Masyarakat dan Jejaring | Vol. 4 | No. 1 | September 2021

mencakup lebih banyak pelanggan. Hubungan baik dengan laboratorium klinik lain diperlukan untuk merujukkan pelanggan yang melakukan pemeriksaan yang tidak dapat dilakukan ke Meditest, ke laboratorium klinik lain tersebut. Selanjutnya, hubungan baik dengan pelanggan, sangat penting untuk membangun kepercayaan pada pelanggan. Baik untuk pelanggan baru maupun pelanggan setia. Hubungan yang baik dapat dijalin dengan cara memberikan pelayanan yang ramah, melaksanakan pemeriksaan dengan hasil yang akurat, serta respon yang cepat. Pelanggan yang puas dengan pelayanan Meditest, dapat membantu mempromosikan Meditest kepada teman dekat, keluarga, atau kenalan lainnya. Pelanggan yang ingin melakukan jenis pemeriksaan tertentu yang tidak dapat dilakukan di Meditest, tetap dapat dilayani yaitu dengan mengirimkan sampel pelanggan tersebut untuk diproses di laboratorium klinik lain, berkat hubungan baik Meditest kepada laboratorium klinik lain itu. Pelanggan tidak usah khusus pergi ke laboratorium klinik lain jadi akan menghemat waktu. Kesan positif yang dirasakan pelanggan diharapkan membuat pangsa pasar Meditest menjadi lebih luas. Selanjutnya, untuk faktor penggunaan teknologi informasi mendapatkan nilai ketertarikan tertinggi yaitu 4. Teknologi informasi sudah menjadi hal umum di masa saat ini terutama media sosial, di mana sudah banyak orang yang memiliki akses internet. Media sosial dapat menjadi alat yang efektif untuk pemasaran yang dilakukan Meditest serta dapat digunakan untuk memberikan informasi tentang hasil atau follow-up dari pemeriksaan yang sudah dilakukan pasien. Pasien dapat dengan segera mengetahui hasilnya.

Terakhir, pada faktor Ancaman, nilai ketertarikan 3 diberikan pada faktor persaingan yang ketat antar laboratorium klinik serta saling menurunkan harga antar laboratorium klinik. Kedua faktor tersebut cukup penting untuk strategi penetrasi pasar. Harga masih menjadi penentu seseorang untuk memutuskan mana laboratorium klinik untuk memeriksakan kondisi kesehatannya. Persaingan antara laboratorium klinik juga berfokus pada penurunan harga demi menarik perhatian orang-orang untuk periksa, karena dirasa kehadiran BPJS Kesehatan berdampak pada penurunan jumlah pasien/pelanggan. Selanjutnya, nilai 2 diberikan pada dua faktor yaitu pemberlakuan BPJS Kesehatan serta apotik dan mal yang turut mengadakan pemeriksaan kesehatan.

Strategi penetrasi pasar menurut David (2011) adalah strategi yang dilakukan oleh perusahaan untuk meningkatkan pangsa pasar produknya di pasar yang sudah ada, umumnya melalui peningkatan kegiatan pemasaran. Meskipun begitu tidak hanya pemasaran, tapi juga pelayanan yang baik kepada pelanggan serta harga yang bersaing. Dari matriks SWOT, strategistrategi yang dihasilkan dapat dihubungkan dengan strategi penetrasi pasar. Strategi SO (strength-opportunity), seperti pelayanan yang tanggap dan ramah dianggap bisa memberikan kesan positif bagi pasien pelanggan dan berpotensi memberitahukan kesan positif itu ke orangorang lain, sehingga diharapkan lebih banyak orang yang menjadi pelanggan baru Meditest. Melakukan promosi lebih gencar melalui media sosial berarti meningkatkan aktivitas pemasaran, kemudian memberitahukan pasien tentang pemeriksaan berikutnya merupakan bentuk perhatian yang diberikan Meditest kepada pasien. Strategi ST (strength-threat) yang terdiri atas mengadakan promo harga yang sewajarnya serta mengadakan penyuluhan kesehatan terutama mengenai penyakit yang sedang relevan, bisa berguna untuk meraup lebih banyak pangsa pasar. Khususnya saat pandemi Covid-19, Meditest menganjurkan orang-orang agar melakukan vaksinasi untuk penyakit lain, seperti PCV (pneumococcal conjugate vaccine) untuk menghindari penyakit pneumonia, meningitis, dan otitis media. 
Praxis : Jurnal Sains, Teknologi, Masyarakat dan Jejaring | Vol. 4 | No. 1 | September 2021

PCV ini memang tidak dapat melindungi dari virus korona, melainkan bermaksud untuk mencegah infeksi sekunder pada paru-paru dan otak. Apabila seseorang tertular Covid-19, daya tahan tubuhnya menurun drastis sehingga rentan terkena infeksi penyakit sekunder yang membuat kondisi kesehatan semakin buruk. Pemberian PCV berguna untuk mencegah infeksi sekunder tersebut. Pandemi ini dianggap sebagai ancaman yang berdampak pada masyarakat takut untuk periksa kesehatan, tapi sekaligus dapat dipandang sebagai peluang, misalnya mengadakan pemeriksaan cepat atau rapid test. Ketika orang akan bepergian ke luar daerah atau luar negeri, rapid test menjadi syarat wajib. Oleh karena itu terdapat potensi meraup pangsa pasar yang lebih banyak, sehingga kedua layanan ini bisa mendukung penetrasi pasar.

\section{PENUTUP}

\section{Kesimpulan}

Hasil analisis dengan matriks IFE dan EFE menunjukkan nilai masing-masing adalah 2,95 dan 2,82, yang selanjutnya titik pertemuan antara kedua nilai digambarkan pada matriks IE, berada dalam kuadran $\mathrm{V}$ yang berarti termasuk dalam kategori menjaga dan mempertahankan, sehingga strategi yang disarankan adalah penetrasi pasar atau pengembangan produk. Pada tahap berikutnya yaitu menggunakan matriks perencanaan strategi kuantitatif (QSPM), strategi yang cocok adalah penetrasi pasar.

Strategi penetrasi pasar memiliki tujuan untuk mendapatkan pangsa pasar yang lebih besar pada pasar yang sudah ada dan menggunakan produk yang sudah ada. Beberapa cara untuk penetrasi pasar antara lain mengintensifkan pemasaran, pengaturan harga produk, dan upaya untuk menjadikan pelanggan setia dengan produknya. Promosi secara intensif dan agresif dilakukan melalui media sosial yang sering digunakan masyarakat banyak saat ini seperti Whatsapp dan Instagram. Dengan demikian ada potensi masyarakat untuk mengetahui keberadaan Meditest dan produk-produknya. Menempatkan baliho kecil di jalan protokol Ahmad Yani bisa dipertimbangkan, agar orang yang sering melewati jalan itu dapat lebih mudah menemukan Meditest. Pada pelayanan pada pelanggan, harus terus dipastikan bahwa karyawan melayani dengan ramah, tepat, dan tanggap, agar membangun kepercayaan pelanggan. Penyuluhan tentang kesehatan untuk meningkatkan kesadaran masyarakat, misalnya untuk periksa kesehatan dan vaksinasi, juga terus dilakukan.

Pada masa pandemi Covid-19, di satu sisi awalnya dianggap sebagai ancaman yang menyebabkan orang-orang makin enggan untuk periksa kesehatan, namun selanjutnya di sisi lain dapat dipandang sebagai peluang baru, di antaranya rapid test untuk mengetahui apakah seseorang positif Covid atau negatif, serta pandemi ini menyebabkan orang semakin sadar diri dengan kesehatannya. Makin banyak orang yang mau divaksin, terutama pneumonia dan meningitis. Ada persyaratan rapid test bagi orang-orang yang ingin bepergian ke luar daerah atau luar negeri. Meditest saat ini sudah menawarkan layanan rapid test serta vaksinasi bagi masyarakat yang membutuhkan di saat pandemi ini. Kedua layanan ini sebenarnya bisa mendukung penetrasi pasar.

\section{Saran}

Ada beberapa saran yang dapat diberikan berdasarkan penelitian ini. Pertama, perlu menggencarkan aktivitas pemasaran. Menggunakan media sosial semisal Whatsapp atau Instagram bisa lebih efektif karena kedua platform ini adalah yang paling banyak digunakan oleh masyarakat. Kegiatan promosi ini juga sebaiknya 
Praxis : Jurnal Sains, Teknologi, Masyarakat dan Jejaring | Vol. 4 | No. 1 | September 2021

dibarengi dengan penyuluhan kesehatan untuk menyadarkan masyarakat luas akan pentingnya pemeriksaan kesehatan dan vaksinasi. Permasalahan kesehatan yang relevan dapat menjadi dasar bagi penyuluhan ini. Pemasangan baliho kecil atau sign di jalan protokol Ahmad Yani pada belokan langsung ke jalan Admodirono, dirasa diperlukan untuk memudahkan masyarakat dalam menemukan Meditest.

Saran berikutnya, manajemen Meditest perlu mempertimbangkan untuk meremajakan peralatan-peralatan lab yang menunjang produktivitasnya. Mengingat produk peralatan atau mesin lab ini juga mengalami perkembangan teknologi seiring berjalannya waktu sehingga efektivitas dan efisiensi meningkat. Selain itu, kemungkinan bahwa suku cadang peralatan model lama tidak diproduksi lagi, sehingga berpengaruh pada pemeliharaannya.

Peneliti menemui keterbatasan dalam penelitian ini, di antaranya keterbatasan waktu untuk narasumber serta ragam data yang didapat. Namun diharapkan penelitian ini bisa menjadi inspirasi bagi peneliti lain untuk melakukan penelitian pada obyek yang serupa pada laboratorium klinik atau fasilitas kesehatan lain.

\section{DAFTAR PUSTAKA}

Afrianto (2020). Pandemi: Dari Kesehatan, Ekonomi, hingga Politik. Bebas.kompas.com. Retrieved from https://bebas.kompas.id/baca/riset/202 0/07/17/pandemi-dari-kesehatanekonomi-hingga-politik/ (akses 3 Desember 2020).

Cahyawati, A. N., Sulistyarini, D. H., \& Swara, S. E. (2016). Analisis Perumusan Strategi Di $X$ Travel Dengan Metode Qspm. JIEM, 1(2), 35-41. Retrieved from https://jurnal.teknologiindustriumi.ac.i d/index.php/JIEM/article/view/82 (akses 17 Oktober 2018)

David, F. R. (2011). Manajemen Strategis. terj. Dono Sumardi (12th ed.). Jakarta: Salemba Empat.

David, M. E., David, F. R., \& David, F. R. (2009). The Quantitative Strategic Planning Matrix (Qspm) Applied To a Retail Computer Store. The Coastal Business Journal, 8(1), 42-52. Retrieved from http://citeseerx.ist.psu.edu/viewdoc/su mmary?doi=10.1.1.524.9919 Oktober 2018)

Hunger, J.D. \& Wheelen, T.L. (2003). Manajemen Strategis. terj. Julianto Agung (5th ed.) Yogyakarta: Andi.

Irwandy (2020). 4 gelombang besar pandemi Covid-19 menghantam sistem pelayanan kesehatan. Theconversation.com. Retrieved from https://theconversation.com/4gelombang-besar-pandemi-covid-19menghantam-sistem-pelayanankesehatan-142049 (akses 3 Desember 2020).

Islam, Alam (2020). Laboratorium dan Klinik Kesehatan Ikut Sepi. Radarlampung.com. Retrieved from https://radarlampung.co.id/2020/04/21 /laboratorium-dan-klinik-kesehatanikut-sepi/ (akses 3 Desember 2020).

Mulyono, B. (2007). Manajemen Laboratorium: Penentuan Strategik Prioritas Pelayanan Laboratorium Klinik Menggunakan Teknik SFAS (Strategic Factors Analysis Summary) Bersarana Acuan SWOT. Indonesian Journal of Clinical Pathology and Medical Laboratory, 13(2), 82-92. Retrieved from https://indonesianjournalofclinicalpath ology.org/index.php/patologi/article/vi ew/889 (akses 24 Juni 2018)

Nurhakim, A. S., Suparno, O., \& Nurrochmat, D. R. (2018). Pengembangan Model Bisnis dan Strategi Pelayanan Kesehatan XYZ. Jurnal Aplikasi Manajemen Dan 
Praxis : Jurnal Sains, Teknologi, Masyarakat dan Jejaring | Vol. 4 | No. 1 | September 2021

Bisnis, 4(2), 251-260. Retrieved from http://jurnal.ipb.ac.id/index.php/jabm/ article/view/21326 (akses 7 Oktober 2018)

Pearce II, J. A., \& Johnson Jr., R. B. (2013). Manajemen Strategis: Formulasi, Implementasi, dan Pengendalian. terj. Nia Pramita Sari (12th ed.). Jakarta: Salemba Empat.

Peraturan Menteri Kesehatan RI Nomor 411/MENKES/PER/III/2010 tentang Laboratorium Klinik.

Purnawati, S. (2013). Design Analisa Kebutuhan Pelaporan Hasil Medical Check Up Di Laboratorium Kualita Medica. Retrieved from http://eprints.dinus.ac.id/7733/ (akses 1 Juli 2018)

Sekaran, U. (2011). Metode Penelitian Untuk Bisnis. Buku 2. Edisi 4. terj. Kwan Men Yon (4th ed.). Jakarta: Salemba Empat.

Sugianto, C. A., \& Hongdiyanto, C. (2017). Perumusan Strategi Pemasaran Menggunakan Metode QSPM Pada Bisnis Sambal Noesantara. Jurnal Manajemen Dan Start-up Bisnis, 2(1), 106-115. Retrieved from https://journal.uc.ac.id/index.php/perfo rma/article/view/443 (akses 8 Oktober 2018)

Sugiyono. (2012). Metode Penelitian Pendidikan Pendekatan Kuantitaif, Kualitatif, dan R\&D. Bandung: Alfabeta.

Yazdani, M., Larijani, A. L., Zarimohaleh, S. T., \& Monavarian, A. (2012). Developing Optimized Strategy by Comprehensive Framework of Strategy; Case Study in a Construction Inspection Company. Procedia - Social and Behavioral Sciences, 58, 73-83. http://doi.org/10.1016/j.sbspro.2012.0 9.980 (akses 8 Oktober 2018) 